\title{
Problems of exhaust gas emission of modernized diesel locomotives operating in Poland
}

\begin{abstract}
This article presents the analysis of emissivity of diesel locomotives operating in Poland. In the last years a significant part of the rail vehicles have been subjected to remotorization consisting in replacement of the combustion engine with the new generation model. This leads to the reduction of toxic constituents emission of exhaust gases from the railway vehicles. The analysis was conducted bearing in mind the histograms of locomotives loads in normal work conditions. It allowed to assess the ecological benefits of these engines during their operation.
\end{abstract}

Key words: tests of diesel locomotives, exhaust gas emission

\section{Problemy emisji spalin z modernizowanych lokomotyw spalinowych eksploatowanych w Polsce}

\begin{abstract}
$W$ artykule przedstawiono analizę emisyjności eksploatowanych lokomotyw spalinowych w Polsce. Znaczna część pojazdów szynowych $w$ ciagu ostatnich lat poddano remotoryzacjom polegajacym na zastapieniu silnika spalinowego nowszym generacyjnie modelem. Skutkuje to zmniejszeniem emisji składników toksycznych spalin z pojazdów szynowych. Analizę przeprowadzono z uwzględnieniem histogramów obciązeń lokomotyw w typowych warunkach pracy, co pozwolito na ocenę korzyści ekologicznych związanych z tymi silnikami w czasie ich eksploatacji.
\end{abstract}

Słowa kluczowe: badania lokomotyw spalinowych, emisja spalin

\section{Introduction}

During several dozen years in the countries of European Union the various legal instruments to improve air quality by controlling the emission of harmful pollutants for the human health and the natural environment are proposed and implemented. The values of emission of the harmful constituents in the European Union have been decreasing because of the stringent restrictions. The trend of reduction of most harmful compounds emission is observed. In the years 1990-2010 the total emission of carbon monoxide into the atmosphere was reduced by about $62 \%$ and nitrogen oxides by about $47 \%$ [9]. The percentage changes of emission for each pollutant of EU economic sectors in the total emission of the particular pollutant in 2012 (the data cover 27 countries) are presented in Fig. 1. The critical ones for the rail vehicle engines are emissions of nitrogen oxides and particles. Their significant reduction dates at the turn of the nineties of XX century

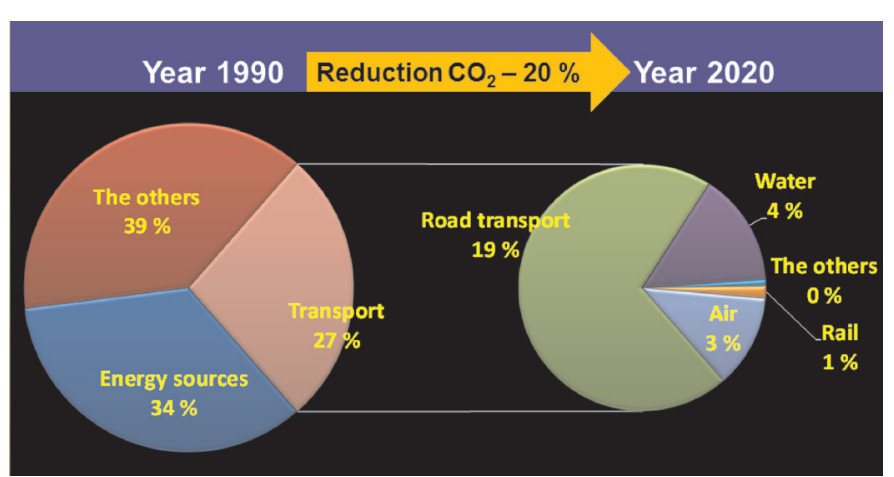

Fig. 1. Carbon dioxide emissions from the transport sector (EU-27) [10]

Rys. 1. Emisja dwutlenku węgla z sektora transportowego (EU-27) [10]

\section{Wprowadzenie}

W okresie kilkudziesięciu lat w krajach Unii Europejskiej zaproponowano i wdrożono różne prawne instrumenty $\mathrm{w}$ celu poprawy jakości powietrza atmosferycznego przez kontrolowanie emisji zanieczyszczeń szkodliwych dla zdrowia człowieka i jego środowiska naturalnego. Emisja składników szkodliwych spalin w Unii Europejskiej, ze względu na zaostrzane ograniczenia, przyjmuje coraz mniejsze wartości. Obserwuje się trend ograniczania emisji większości szkodliwych związków. W latach 1990-2010 zmniejszeniu uległa emisja całkowita do atmosfery tlenku węgla o około $62 \%$ oraz tlenków azotu o około 47\% [9]. Procentowe zmiany emisji poszczególnych zanieczyszczeń z unijnych sektorów gospodarki, w całkowitej emisji danego zanieczyszczenia w 2012 r. (dane obejmują 27 państw) przedstawiono na rys. 1. Krytyczne dla silników pojazdów szynowych są emisje tlenków azotu oraz cząstek stałych. Ich znaczne obniżenie datuje się na lata dziewięćdziesiąte XX wieku (rys. 2). Największe zmiany dotyczą pojazdów szynowych, a nie lokomotyw spalinowych.

Pomiary emisji prowadzi się obecnie według testu NRSC znanego jako test stacjonarny ISO 8178-F (rys. 3). Spalinowe pojazdy szynowe, podobnie jak pojazdy drogowe, podlegają normom emisji spalin określanym przez Unię Europejską. Dla nowych pojazdów od stycznia 2012 r. obowiązuje etap III B, normujący maksymalną wielkość zanieczyszczeń w spalinach, a od 31 grudnia 2013 r. wprowadzono etap IV dopuszczający mniejszy poziom zanieczyszczeń. Aktualny stan prawny w zakresie norm czystości spalin dla pojazdów kolejowych określa dyrektywa 2004/26/WE z 21 kwietnia 2004 r. (rys. 4). 
(Fig. 2). The biggest changes concern the rail vehicles and not diesel locomotives.

At present the emission measurements are carried out according to the NRSC test known as the stationary test ISO 8178-F (Fig. 3). The diesel rail vehicles as well as the road vehicles are subject to the standards of exhaust gas emission defined by the European Union. Since January 2012 for the new vehicles the Stage III B has been in effect which regulates the maximum amount of pollutants in the exhaust gases, and since 31 December 2013. the stage IV allowing the lower level of pollution will be introduced. The current legal status of exhaust gas cleanness standards for the rail vehicles is determined by Directive 2004/26/EC of 21 April 2004. (Fig. 4).

The environmental assessment of rail vehicles for the most cases is based on a comparison of the current state of the combustion engine (its value of emission) with the acceptable values of the harmful constituents
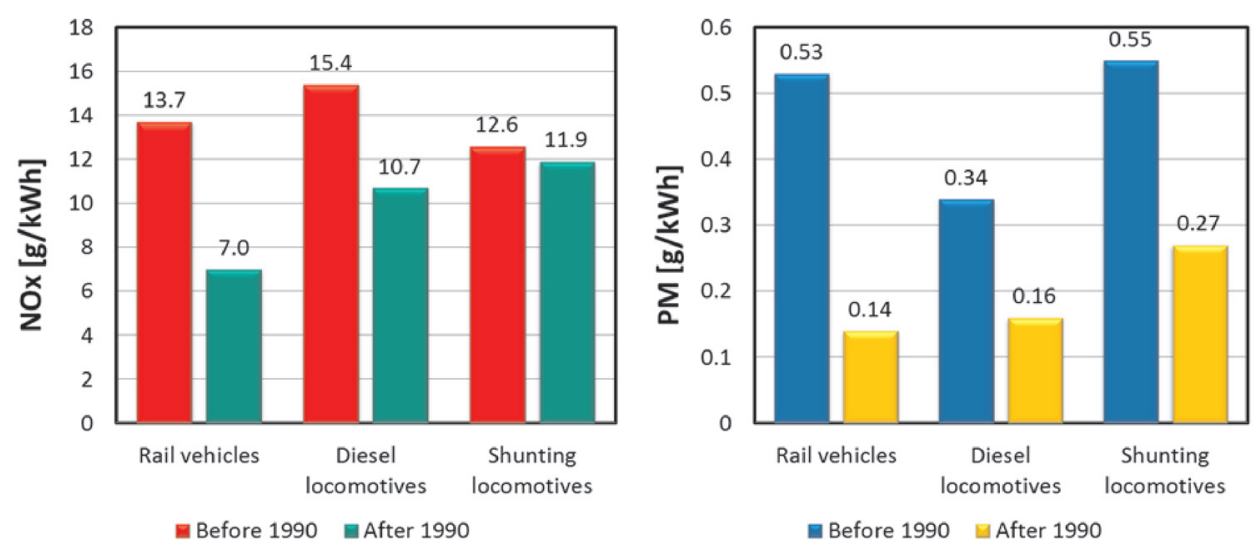

Fig. 2. The average emissions of selected types of rail vehicles [11] Rys. 2. Średnia emisja z wybranych typów pojazdów szynowych [11]

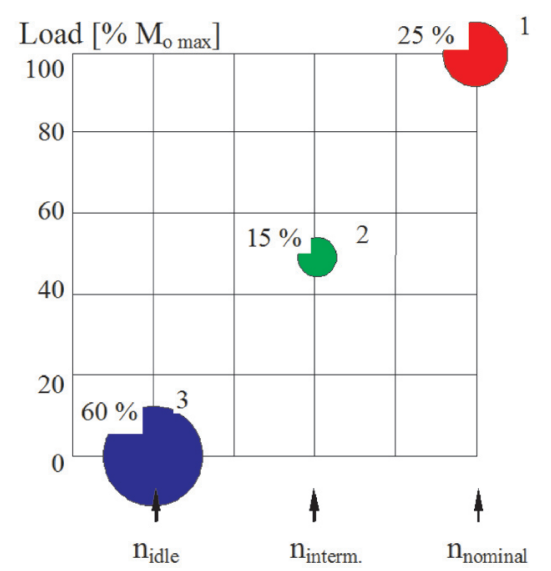

Fig. 3. The current stationary test ISO 8178-F [2] Rys. 3. Obowiazujący test stacjonarny ISO 8178-F [2]
Ocena ekologiczności pojazdów szynowych jest oparta w większości na porównaniu stanu bieżącego silnika spalinowego (jego wartości emisji) z wartościami dopuszczalnymi emisji składników szkodliwych. Wartości te dotyczą konkretnych testów badawczych silników lub pojazdów [2, 6]. W krajowych warunkach eksploatacji pojazdów szynowych wymagania te są nieco inne, gdyż posiadanie szerokiego spektrum taboru kolejowego znacząco zmienia obraz ekologiczności tych pojazdów. Badania emisji spalin wykonywane na podstawie testu ISO 8178-F pozwalają na odniesienie ich wyników do wartości limitów, jednak nie wskazują na ograniczenie natężenia emisji składników toksycznych. Konieczne staje się więc podjęcie zagadnienia dotyczącego oceny emisyjności silników pojazdów szynowych w warunkach ich rzeczywistej eksploatacji. Podobne działania emission. These values concern the specific research tests of engines or vehicles $[2,6]$. In the national conditions of the rail vehicles operation these requirements are a little different because having a wide

prowadzi się również $\mathrm{w}$ odniesieniu do pojazdów ciężarowych i osobowych $[4,5]$. Zatem wszystkie działania mające na celu ocenę rzeczywistego stopnia emisyjności pojazdów szynowych oraz próby ich poprawy są konieczne i uzasadnione [2].
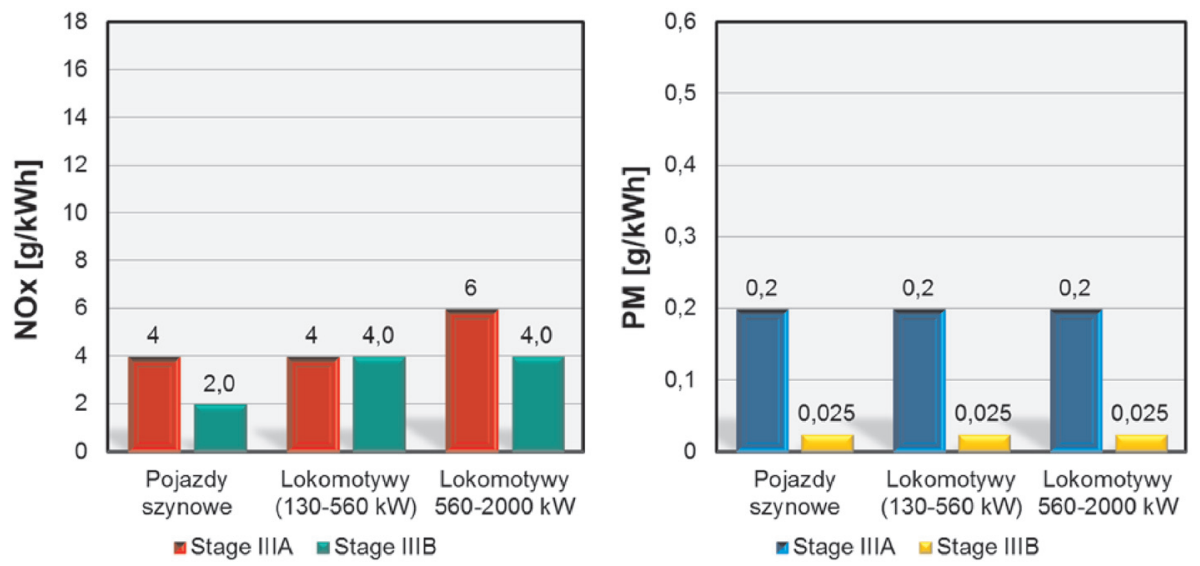

Fig. 4. Limits of exhaust gas emissions of rail vehicles [11]

Rys. 4. Limity emisji spalin pojazdów szynowych [11]
Obecnie brak jest analiz dotyczących wymiernych korzyści, jakie uzyskuje się w wyniku napraw silników lub remotoryzacji (wymiany silników) w aspekcie ekologicznym. Udział pojazdów szynowych w ogólnym zanieczyszczeniu środowiska nie jest znaczny (rys. 5).

Głównym celem prac badawczych prezentowanych $\mathrm{w}$ artykule była odpowiedź na pytanie, jakie wymierne korzyści następują w wyniku naprawy głównej silnika lub jego zastąpienia nowszą technologicznie konstrukcją. W tym celu wykonano pomiary 
range of rolling stock significantly changes the environmental view of these vehicles. The tests of exhaust gases emission carried out on the basis of test ISO 8178-F allow to relate their results to the limit values, but they do not show the limitation of concentration of the toxic components emission. Therefore, it is become necessary to take issue of the assessment of rail vehicle engines emissivity in conditions of their actual operation. The similar activities are also carried out for trucks and cars [4, 5]. Thus, all activities to assess the actual degree of emissivity of rail vehicles and to try to improve them are neces-

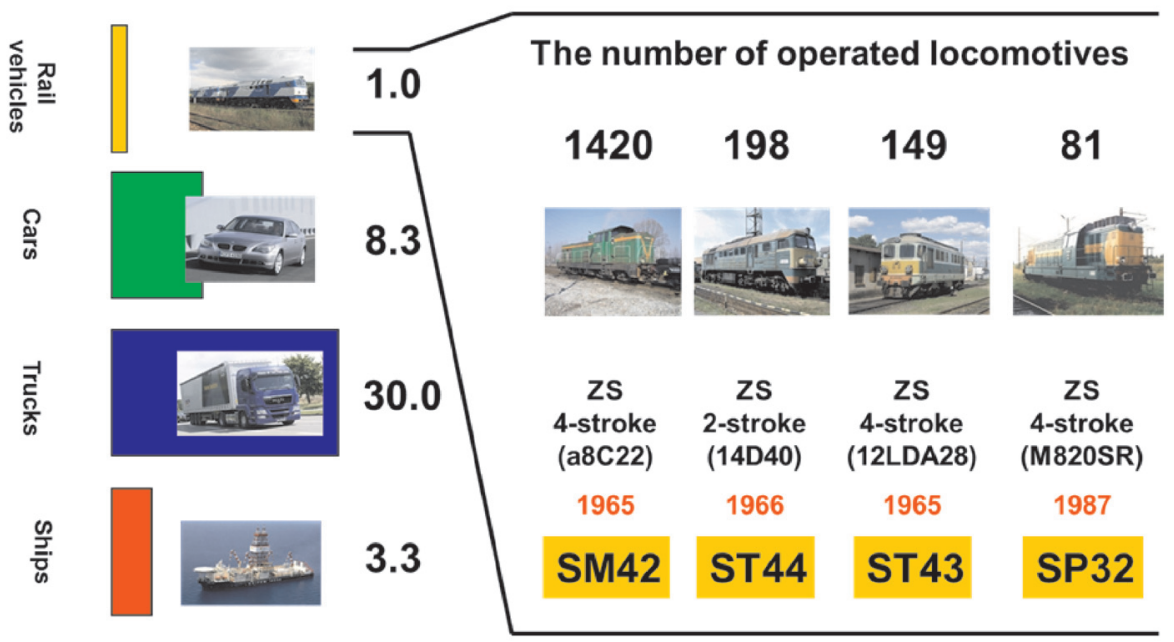
sary and justified [2].

Currently, there is no analysis of measurable benefits achieved as a result of repair or remotorization (replacement of engines) in the aspect of ecology. Contribution of the rail vehicles in the general pollution is not significant (Fig. 5).

The main objective of the research works presented in this article is to answer the question what measurable benefits are as a result of engine overhaul or replacement it with the newer technological design. For this purpose, the measurements of emission of exhaust gases toxic components in diesel locomotives are carried out in accordance with test ISO 8178-F.

\section{Quantitative state of diesel locomotives}

The repair or replacement of the combustion engine is connected with both economic and environmental benefits. The economic benefits include the lower fuel consumption, the use of modern control and combustion engine control systems. Now, the PKP Cargo has almost equal numbers of both the electric vehicles and the diesel ones. These numbers are as follows: 1225 and 1277 units (state at the end of 2011). However, it should be noted that the diesel shunting locomotives (982 units) were the most of diesel vehicle. As a result, the electric locomotives were majority of the regular fright stock.

emisji składników toksycznych spalin w lokomotywach spalinowych zgodnie z testem ISO 8178-F.

\section{Stan ilościowy lokomotyw spalinowych}

Naprawa lub wymiana silnika spalinowego wiąże się zarówno z korzyściami ekonomicznymi, jak i ekologicznymi. Korzyści ekonomiczne to m.in. mniejsze zużycie paliwa, zastosowanie nowoczesnych systemów sterowania i kontroli silnika spalinowego. Obecnie PKP Cargo posiada w niemal równej liczbie zarówno pojazdy elektryczne - 1225 sztuk, jak i spalinowe - 1277 sztuk (stan na koniec 2011 r.). Należy jednak zwrócić uwagę na to, iż większość pojazdów spalinowych stanowiły lokomotywy manewrowe (982 szt.). W rezultacie liniowy tabor do przewozu ładunków stanowiły w większości lokomotywy elektryczne.

Średni wiek taboru w tej firmie wynosi 33,8 lat. Wskaźnik ten nie uwzględnia modernizacji lokomotyw, szczególnie spalinowych, którą przeprowadzano w ostatnich latach. Do zmodernizowanych lokomotyw spalinowych należą ST44 (35 szt.), ST45 (5 szt.) oraz SM42 (49 szt.).

$\mathrm{Z}$ tego względu w tabeli 1 podano skalę i wymiary silników spalinowych w lokomotywach w kilku poprzednich latach.

Table 1. Costs of new investments (diesel locomotives) [8]

Tabela 1. Koszty nowych inwestycji (lokomotyw spalinowych) [8]

\begin{tabular}{|c|c|c|c|}
\hline \multirow[t]{4}{*}{ PKP } & 2011 & Inspection repairs 59 locomotives/naprawy rewizyjne 59 lokomotyw & \multirow{4}{*}{$\begin{array}{l}\text { Replacement of } \\
\text { locomotive SU45 }\end{array}$} \\
\hline & 2012 & Inspection repairs 150 locomotives/naprawy rewizyjne 150 lokomotyw & \\
\hline & $\begin{array}{c}2013 \text { (to } \\
12.03)\end{array}$ & Purchase of 10 new diesel locomotives/zakup 10 nowych lokomotyw spalinowych & \\
\hline & $\begin{array}{c}\text { I quarter of } \\
2013\end{array}$ & Modernization of 20 locomotives SM42/modernizacja 20 lokomotyw serii SM42 & \\
\hline $\begin{array}{l}\text { PKP } \\
\text { Cargo }\end{array}$ & 2011 & $\begin{array}{l}\text { Modernization of } 130 \text { locomotives SM42 (replacement of engine with Caterpillar type CAT27 and } \\
2 \text { systems Caterpillar type CAT15), ST44 (replacement of engine with a new generation engine of } \\
\text { Kołomna type 12CzN26/26)/modernizacja } 130 \text { lokomotyw SM42 (wymiana silnika na Caterpillar typ } \\
\text { CAT27 oraz } 2 \text { uktady Caterpillar typ CAT15), ST44 (wymiana silnika na silnik nowej generacji firmy } \\
\text { Kołomna typ 12CzN26/26) }\end{array}$ & $\begin{array}{c}\text { Cost of } 400 \mathrm{mln} \\
\mathrm{PLN} / k o s z t 400 \\
m \ln z t\end{array}$ \\
\hline
\end{tabular}


The average age of rolling stock in the company is 33,8 years. This index does not include the locomotive modernization, particularly diesel ones which have been carried out in recent years. The modernized locomotives are ST44 (35 units), ST45 (5 units) and SM42 (49 units).

For this reason, the scale of replacement of combustion engines in locomotives in the past few years is given below (Tab. 1).

\section{Test methodology}

The engines of diesel locomotives operated on PKP lines were subjected to tests. Six diesel locomotives were analysed using different types of engines (Tab. 2). Their technical characteristics are presented in Table 3.

\section{Metodyka badań}

Badaniom poddano silniki lokomotyw spalinowych eksploatowanych na liniach PKP. Analizie poddano sześć lokomotyw spalinowych, wykorzystujących różne typy silników (tab. 2). Ich parametry techniczne zestawiono w tabeli 3 .

\section{Analiza pracy lokomotyw}

Możliwości określenia rzeczywistej emisji z silników pojazdów szynowych wymagają rozpoznania wartości histogramów obciążeń silników spalinowych pojazdów szynowych. Histogramy te są zasadniczo odmienne dla pracy lokomotyw spalinowych w ruchu osobowym oraz towarowym (dotyczy to także pracy manewrowej). Analizie

Table 2. Rail vehicles subjected to the emission tests

Tabela 2. Pojazdy szynowe poddane badaniom emisyjnym

\begin{tabular}{|c|c|c|}
\hline Type of vehicle/typ pojazdu & Engine/silnik & Remarks/uwagi \\
\hline ST44 & $14 \mathrm{D} 40$ & Before regulations/przed regulacjami \\
\hline M62 & $14 \mathrm{D} 40$ & After regulations/po regulacjach \\
\hline BR231 & $5 \mathrm{D} 49$ & Replacement of the engine for the newer model/wymiana silnika \\
nRa nowszy model
\end{tabular}

Table 3. Technical characteristics of the combustion engines subjected to tests

Tabela 3. Parametry techniczne silników spalinowych poddanych badaniom

\begin{tabular}{|c|c|c|c|c|c|c|}
\hline $\begin{array}{l}\text { Type/series of } \\
\text { locomotive }\end{array}$ & Type of engine & $\mathrm{N}_{\mathrm{e}}[\mathrm{kW}]$ & $\begin{array}{l}\text { Arrangement of } \\
\text { cylinders }\end{array}$ & $\mathrm{n}_{\mathrm{Ne}-\max }[\mathrm{rpm}]$ & $\mathrm{V}_{\mathrm{ss}}\left[\mathrm{dm}^{3}\right]$ & $\mathrm{g}_{\mathrm{e}}[\mathrm{g} / \mathrm{kW} \cdot \mathrm{h}]$ \\
\hline Locomotive ST44 & $14 \mathrm{D} 40$ & 1470 & $12 / \mathrm{V}\left(45^{\circ}\right)$ & 750 & 150.6 & 228.0 \\
\hline Locomotive BR231 & $5 \mathrm{D} 49$ & 2208 & $16 / \mathrm{V}\left(42^{\circ}\right)$ & 1000 & 200.8 & 215.6 \\
\hline Locomotive R231 & CAT3606 & 1975 & $6 / \mathrm{R}$ & 1000 & 110.8 & 198.0 \\
\hline Locomotive EM62 & $645 \mathrm{E} 3 \mathrm{~B}$ & 2238 & $16 / \mathrm{V}\left(45^{\circ}\right)$ & 893 & 105.7 & - \\
\hline Locomotive M62 & $12 \mathrm{CzN} 26 / 26$ & 1470 & $12 / \mathrm{V}\left(60^{\circ}\right)$ & 750 & 150.6 & 202.5 \\
\hline
\end{tabular}

\section{Analysis of locomotive operation}

The possibilities to determine the actual emission from the engines of rail vehicles require the recognition of histogram values of combustion engine loads of the rail vehicles. These histograms are generally different for the operation

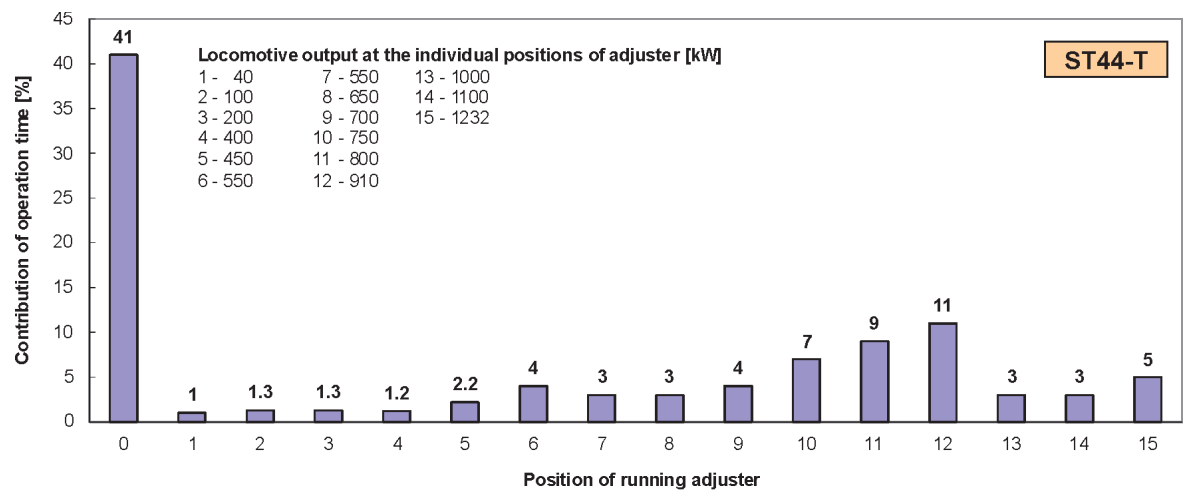

Fig 6. Load histogram of locomotive ST44 operating in freight traffic Rys. 6. Histogram obciazzeń lokomotywy ST44 pracujacej w ruchu towarowym poddano warunki pracy lokomotywy ST44 (rys. 6), gdyż silniki zamieszczone $\mathrm{w}$ tabeli 3 są montowane w takim pojeździe szynowym.

Analiza pracy lokomotywy w warunkach ruchu towarowego pozwala na stwierdzenie:

a) celowego uwzględnienia warunków biegu jałowego w teście badawczym; analizowane lokomotywy wykorzystają znaczne czasy pracy biegu jałowego (po około $40 \%$ );

b) wykorzystywania obciążenia częściowego w niewielkim zakresie, tak więc nie ma podstaw do wykorzystywania tej fazy badań ze znacznym udziałem wagowym;

c) znacznego czasu pracy podczas obciążeń maksymalnych (lub wartości do nich zbliżonych). 
of diesel locomotives in the passenger and freight traffic (including the shunting operation). The conditions of locomotive ST44 operation are subjected to analysis (Fig. 6) because the engines listed in Tables 3 are mounted in such a rail vehicle.

The analysis of locomotive operation in the freight traffic conditions leads to the conclusion:

a) intentional taking into account the conditions of idle running in the research test; the analyzing locomotives use the significant operation times in the idle running (after about $40 \%$ );

b) using the partial load in the small range, so there is no basis to use this phase of tests with a substantial weight participation;

c) the substantial operation time during the maximum loads (or the values closed to them).

\section{Tests of exhaust gases emission in test ISO 8178-F}

The opportunities to reduce the toxic components emission are determined on the basis of small regulatory changes made in the engines of the tested locomotives and in remotorization of the combustion engines - replacement of the engine which is the essential source of the locomotive drive and its replacement with a newer design.

The tests of 2-stroke 14D40 engine before and after regulations are presented on the example of locomotive ST44 M62. The tests were carried out on the water resistor.

The result analysis are referenced to the standards being in force in the relevant years because their comparison to the latest standards does not lead to the formulation of the appropriate conclusions (changes of emissions after engine regulation do not meet the latest standards as the construction technology and the engine controls are not the latest).

The reduction of carbon monoxide emission has been achieved $(66 \%)$ as a result of the carried out regulations (Fig. 7). Such a significant reduction of this component is due to the very large initial emission (before regulation for locomotive). This reflects on the very poor technical state of locomotive subjected to regulation. Even after these the emission of carbon monoxide is significantly exceeded. The emission of hydrocarbons was also reduced over $60 \%$. It should be noted that the initial level was also significant. The values of nitrogen oxide emissions, which after regulations are smaller than the limits of standard ORE B13, result from the fact of non-obtaining the maximum parameters of the combustion engine operation. The lower maximum power is the cause of getting the smaller concentrations of nitrogen oxides and consequently the individual emission.

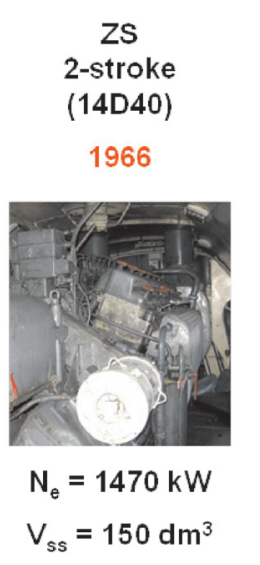

\section{Badania emisji spalin w teście ISO 8178-f}

Możliwości obniżenia emisji składników toksycznych określono na podstawie niewielkich zmian regulacyjnych dokonanych w silnikach badanych lokomotyw oraz remotoryzacji silników spalinowych - wymianie silnika będącego podstawowym źródłem napędu danej lokomotywy i zastąpienia go silnikiem nowszej konstrukcji.

Badania dwusuwowego silnika 14D40 przed regulacjami i po regulacjach przedstawiono na przykładzie lokomotywy ST44 M62. Badania wykonano na oporniku wodnym.

Analizę wyników odniesiono do norm obowiązujących w odpowiednich latach, gdyż porównywanie ich do norm najnowszych nie prowadzi do sformułowania odpowiednich wniosków (zmiany emisji po regulacji silnika nadal nie odpowiadają najnowszym normom, gdyż technologia budowy i sterowania silników nie jest najnowsza).

W wyniku przeprowadzonych regulacji osiągnięto znaczne (66\%) ograniczenie emisji tlenku węgla (rys. 7). Tak znaczne ograniczenie tego składnika spowodowane jest bardzo dużą emisją początkową (dla lokomotywy przed regulacją). Świadczy to o bardzo złym stanie technicznym lokomotywy poddanej regulacjom. Nawet po nich emisja tlenku węgla jest znacznie przekroczona. Emisja węglowodorów również została ograniczona w ponad $60 \%$. Należy podkreślić, że poziom wyjściowy był również znaczny. Wartości emisji tlenków azotu, które po regulacjach są mniejsze niż limity normy ORE B13 wynikają z nieosiągania maksymalnych parametrów pracy silnika spalinowego. Niższa moc maksymalna jest przyczyną uzyskiwania mniejszych wartości stężeń tlenków azotu, a w konsekwencji - emisji jednostkowej.

Dokonano także badań emisji z lokomotywy spalinowej (BR231), w której wymieniono jednostkę spalinową. Silnik 5D49 zastąpiono jednostką firmy Caterpillar 3606 (rys. 8). Silnik ten podczas badań nie spełniał norm ORE B13 z lat 1991-1996. Emisja tlenku węgla i węglowodorów przekroczona była dwu- oraz trzykrotnie (w przypadku HC). Zasto-

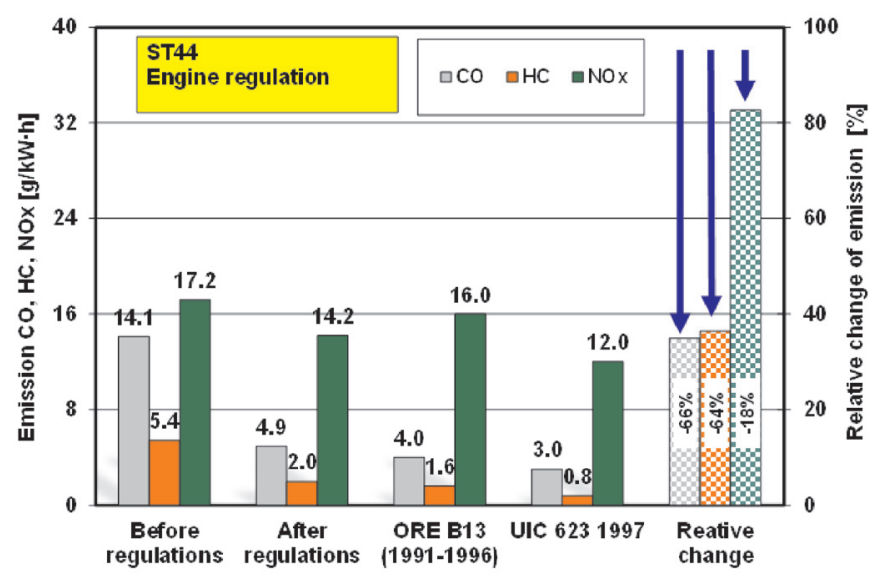

Fig. 7. Test results of unit exhaust gases emission for engine 14D40 of locomotive ST44 M62 No. 1241 before and after regulations

Rys. 7. Wyniki badań emisji jednostkowej spalin dla silnika 14D40 lokomotywy ST44 M62 nr 1241 przed i po regulacjach 
The tests of diesel locomotive emission (BR231), in which the combustion unit was replaced, were carried out. The engine 5D49 was replaced with the Caterpillar 3606 (Fig. 8). During the tests the engine 5D49 did not meet the standards ORE B13 from years 1991-1996. The emissions of carbon monoxide and hydrocarbons were exceeded two and three times (in case of $\mathrm{HC}$ ). The significant reduction of these components emission from this locomotive was a result of application of engine CAT 3606. The emission of carbon monoxide was reduced by $47 \%$. The emission of hydrocarbons was decreased (by $62 \%$ ) to a level allowing to meet the limits of UIC 623. The similar ecological benefits concern the nitrogen oxides: it is possible to meet the limits of UIC.

The replacement of engine in locomotive ST44 is an example of modernization of the existing rolling stock. The reduction of fuel and oil consumption is a result of application of the new 16-cylinder 2-stroke engine of General Electric $645 \mathrm{E} 3 \mathrm{~B}$ with power $2200 \mathrm{~kW}$, that is with power greater by $50 \%$ than the standard. Another modernization is application of the engine $12 \mathrm{CzN} 26 / 26$ in this locomotive. The results of emission measurements in comparison with the standards are shown in Fig. 9.

\section{Assumptions for emission analysis of engines}

All tested engines belonged to the same class of rail vehicle. For this reason the analysis was carried out using the same load histogram and assuming that the contributions of work time in each position of adjuster are the same. With such assumptions the area of 15 positions of adjuster was divided into phases, so as to include the phases of research test ISO 8178-F. Division of adjuster position is
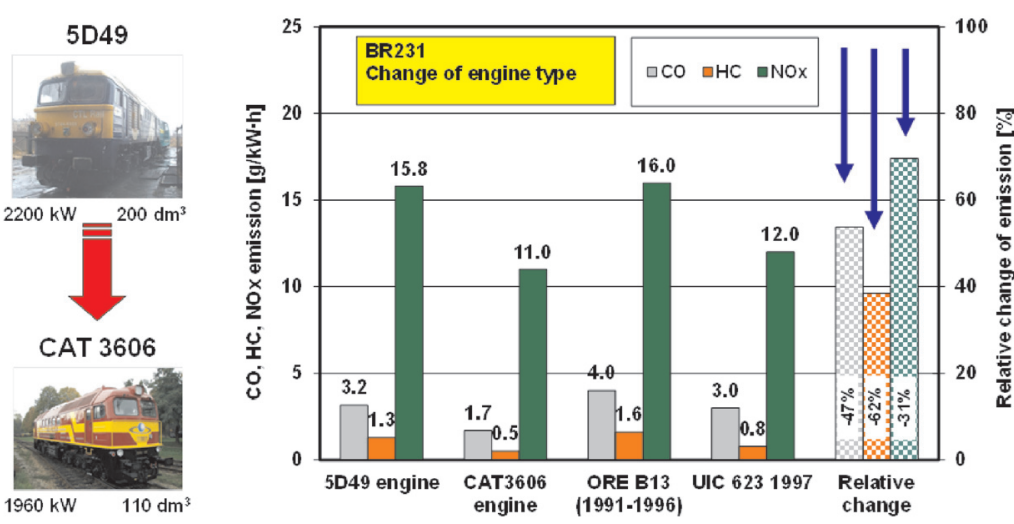

Fig. 8. Test results of unit exhaust gases emission of locomotive BR231 for engine 5D49 and after its replacement with engine CAT 3606

Rys. 8. Wyniki badań emisji jednostkowej spalin lokomotywy BR231 dla silnika 5D49 oraz po jego wymianie na silnik CAT 3606

sowanie silnika CAT 3606 spowodowało znaczną redukcję emisji tych składników z tej lokomotywy. Emisję tlenku węgla obniżono o 47\%. Emisję węglowodorów obniżono (o 62\%) do poziomu, który pozwala na spełnienie limitów normy UIC 623. Podobne zyski ekologiczne dotyczą tlenków azotu: możliwe jest spełnienie limitów normy UIC.
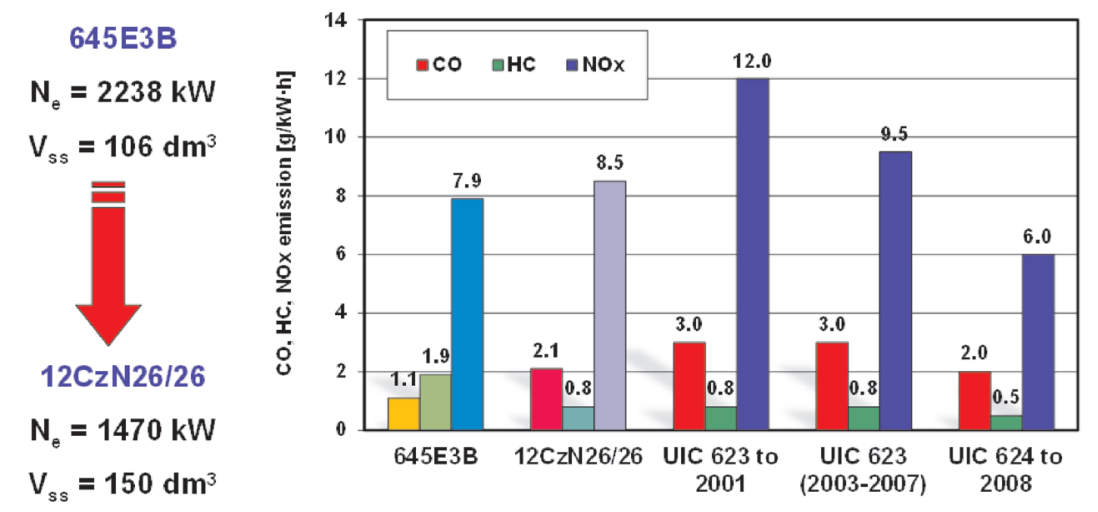

Fig. 9. Emission results of the new engines built in locomotive ST44 Rys. 9. Wyniki emisji nowych silników zabudowanych w lokomotywie ST44 presented in Fig. 10. Based on an arbitrary classification of the adjuster position to the appropriate phase of the research test, the contribution of work time in the individual phases of test is determined. The values of these contributions are shown in Table 5. The analysis of phase contributions confirms the large contribution of idling in the assigned histogram phase. The significant contribution of phase 2. results from the great number of adjuster positions assigned to this phase. Phase 3 includes only 3 positions and its contribution is $11 \%$.

\section{Results of ecological tests}

The emission test results in test ISO 8178-F presented in point 6 were used to determine the concentration of exhaust gas emission in the individual phases of this test. The exemplary analysis of emission from engine 645E3B

Przykładem modernizacji istniejącego taboru kolejowego jest wymiana silnika w lokomotywie ST44. Zastosowanie nowego 16-cylindrowego dwusuwowego silnika firmy General Electric 645E3B o mocy $2200 \mathrm{~kW}$, a więc o mocy większej o 50\% niż standardowy, spowodowało zmniejszenie zużycia paliwa i oleju. Kolejną modernizacją jest zastosowanie w tej lokomotywie silnika 12CzN26/26. Wyniki pomiarów emisji na tle norm przedstawiono na rys. 9.

\section{Zalożenia do analizy emisyjnej silników}

Wszystkie badane silniki należały do tej samej klasy pojazdu szynowego. Z tego względu dokonano analizy, wykorzystując ten sam histogram obciążeń oraz zakładając, że udziały czasu pracy na poszczególnych pozycjach 
a)

b)

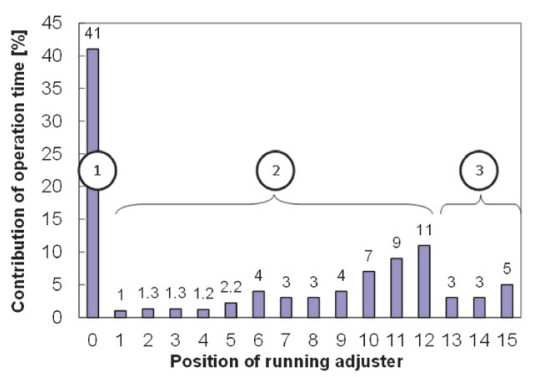

Fig. 10. The way of adjustment of load histogram to ISO $8178-\mathrm{F}$ from the load histograms (b)

Rys. 10. Sposób dopasowania histogramu obciążen do faz testu ISO 8178-F (a) oraz wartości ustalonych udziałów poszczególnych faz wynikających z histogramów obciążenia (b)

indicates that there are much higher values of emission in the individual phases than the resulting value of test (Fig. 11). Certainly, the emission from the entire test takes into account the coefficients of phase contribution. However, during the emission analyses and searching the ecological benefits the knowledge of actual values of emissions in the individual phases of test should be used.

Due to the divergent values of emission of the individual combustion engines, which were presented previously, the

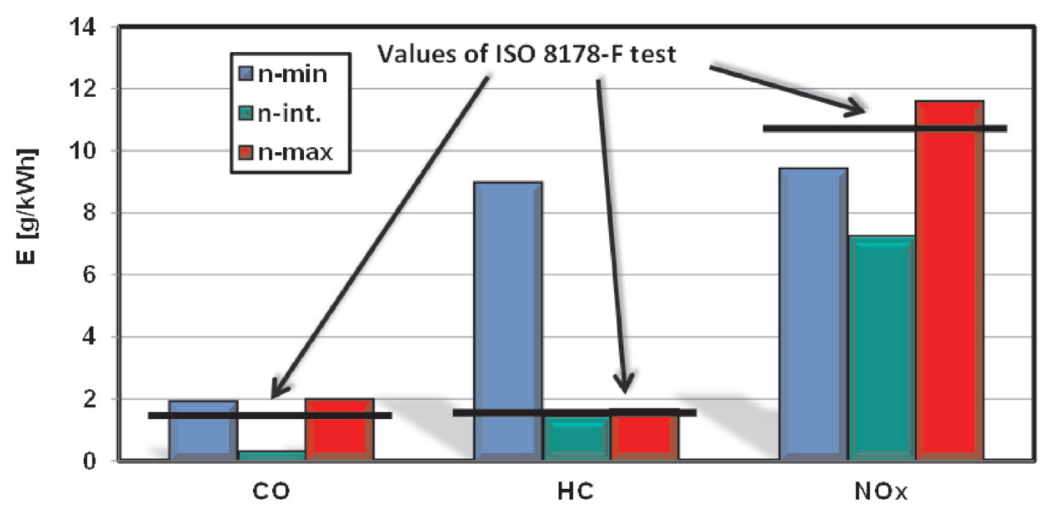

Fig. 11. The values of emission of harmful exhaust gas components from engine 645E3B in the individual phases of research test

Rys. 11. Wartości emisji składników szkodliwych spalin z silnika 645E3B w poszczególnych fazach testu badawczego

calibration was made. The size of emissions of the individual exhaust gas components from test ISO 8178-F was obtained with reference to the maximum size of the each of analyzed components of exhaust gases. The changes, which show that the engine 14D40 before its repair is characterized by the largest emission of exhaust gas components, were obtained (Fig. 12a). However, the carried out repair allowed to obtain a small improvement of emission of exhaust gas components in comparison with other combustion engines. It follows from this that the contribution of engine in the environmental pollution was significantly reduced. However, the level of emission does not correspond to other engines. nastawnika są jednakowe. Przyjmując takie założenia, podzielono obszar 15 pozycji nastawnika na fazy, tak aby obejmowały one swym udziałem fazy testu badawczego ISO 8178-F. Podział pozycji nastawnika przedstawiono na rys. 10 . Na podstawie arbitralnego zakwalifikowania pozycji nastawnika do odpowiedniej fazy testu badawczego wyznaczono udział czasu pracy w poszczególnych fazach testu. Wartości tych udziałów przedstawiono w tabeli 5. Analiza udziałów faz potwierdza duży udział fazy biegu jałowego w przyporządkowanej fazie histogramu. Znaczny udział fazy 2. wynika z dużej liczby pozycji nastawnika przypisanej do tej fazy. Faza trzecia obejmuje tylko 3 pozycje i jej udział wynosi $11 \%$.

\section{Wyniki badań ekologicznych}

Wyniki badań emisji w teście ISO 8178-F przedstawione wyżej wykorzystano do określenia natężenia emisji spalin w poszczególnych fazach tego testu. Przykładowa analiza emisji z silnika 645E3B wskazuje na istnienie znacznie większych wartości emisji w poszczególnych fazach niż wartość wynikowa z testu (rys. 11). Oczywiście emisja z całego testu uwzględnia współczynniki udziału faz, jednak podczas analiz emisyjnych i poszukiwania korzyści ekologicznych należy wykorzystać wiedzę dotyczącą rzeczywistych wartości emisji w poszczególnych fazach testu.

Z uwagi na przedstawione poprzednio rozbieżne wartości emisji poszczególnych silników spalinowych dokonano ich skalania. Uzyskano wielkości emisji poszczególnych składników spalin z testu ISO 8178-F w odniesieniu do wielkości maksymalnych każdego z analizowanych składników spalin. Uzyskano zmiany (rys. 12a), które wskazują, że największą emisją składników spalin cechuje się silnik 14D40 będący przed naprawą. Jednak przeprowadzona naprawa pozwoliła na uzyskanie niewielkiej poprawy emisji składników spalin w stosunku do innych silników spalinowych. Wynika z tego, 
a)

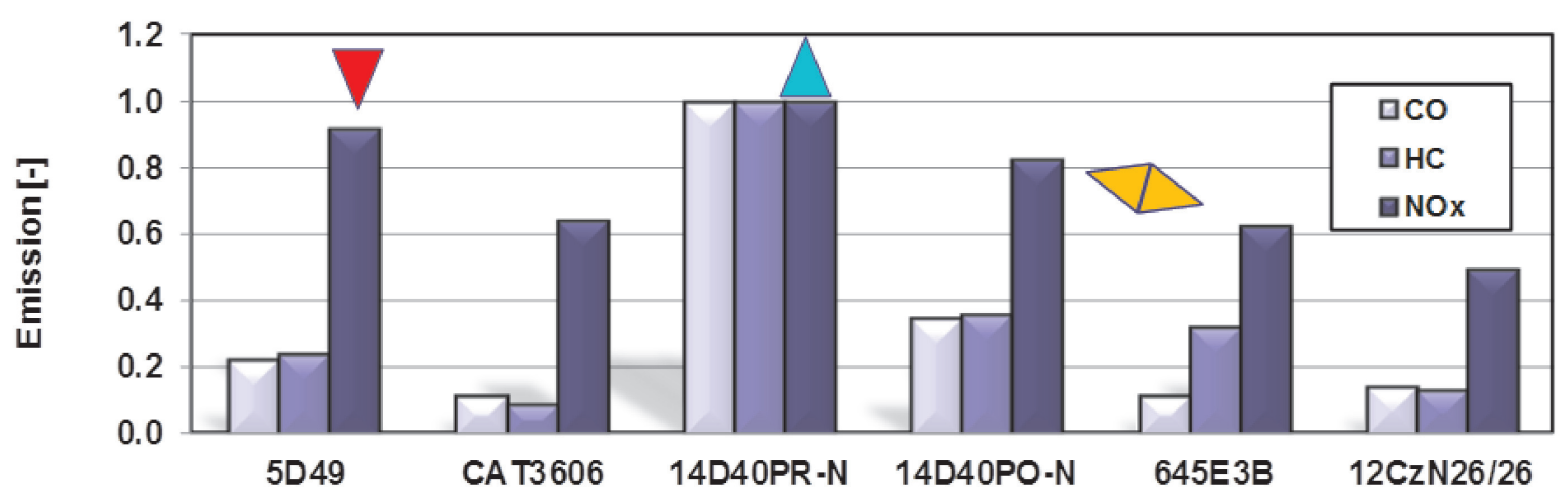

b)

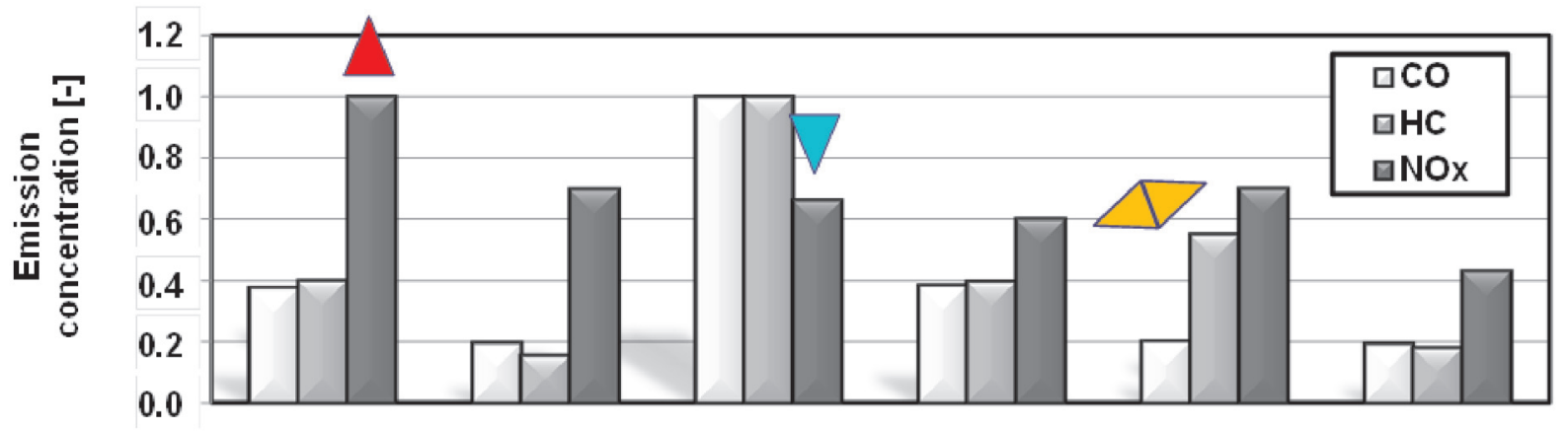

Fig. 12. Standarized values: a) emission [g/kWh], b) intensities of individual exhaust gas components Rys. 12. Normowane wartości: a) emisji [g/kWh], b) natężenia poszczególnych składników spalin

The emission of harmful components obtained as concentration of the exhaust gas component in the individual phases of the test allows to determine the mass of the emitted toxic compounds. In this case the engine power is not considered (Fig. 8b). The analysis of results shows some difference from the results presented in Fig. 8a. This allows to find that the values of emission are not as important as the values of concentration of the analyzed exhaust gas components. On this basis, in the further part of the article the analysis of harmful exhaust gas components concentration was taken up because they mainly make the air pollution.

\subsection{Emission reduction by the engine repair}

The emission effectiveness of replacement of combustion engine was analyzed. Having the results of exhaust gas emission in test ISO 8178-F and assigned contributions of settings from load histograms, the calculations of the effective limit of real values of exhaust gas components emission during operation of freight locomotive ST44 equipped with engine 14D40 before and after repair were done. Having these data, it is possible to determine the benefits resulting from operation time of this locomotive. The significant reduction of pollutants mass was obtained (to 55\% for hydrocarbons) (Fig. 13). These values apply to hourly emission concentration of the individual exhaust gas components.

\subsection{Emission reduction by the engine replacement}

The result of combustion engine replacement (replacement of engine 14D40 with engine $645 \mathrm{E} 3 \mathrm{~B}$ ) is reduction of emission concentration of all exhaust gas components. This że zmniejszono znacznie udział silnika w zanieczyszczaniu środowiska, jednak poziom emisji nie koresponduje z pozostałymi silnikami.

Emisja składników szkodliwych uzyskana jako natężenie danego składnika spalin w poszczególnych fazach testu pozwala na wyznaczenie masy wyemitowanych związków toksycznych. W tym wypadku nie uwzględnia się mocy silnika (rys. 8b). Analiza wyników wskazuje na pewną odmienność od przedstawionych wyników na rys. 8a. Pozwala to stwierdzić, że wartości emisji nie są tak istotne, jak wartości natężenia analizowanych składników spalin. Na tej podstawie w dalszej części artykułu zajęto się analizą natężenia składników szkodliwych spalin, gdyż one głównie stanowią o zanieczyszczeniu powietrza.

\subsection{Ograniczenie emisji przez naprawę silnika}

Analizie poddano efektywność emisyjną wymiany silnika spalinowego. Dysponując wynikami emisji spalin w teście ISO 8178-F oraz przypisanymi udziałami nastaw z histogramów obciążeń, dokonano obliczeń efektywnego ograniczenia rzeczywistych wartości emisji składników spalin podczas pracy towarowej lokomotywy ST44, wyposażonej w silnik 14D40 przed i po naprawie. Dysponując takimi danymi, możliwe jest określenie korzyści wynikających z czasu pracy takiej lokomotywy. Uzyskano znaczące (do 55\% dla węglowodorów) zmniejszenie masy zanieczyszczeń (rys. 13). Wartości te dotyczą natężenia godzinowych emisji poszczególnych składników spalin.

\subsection{Ograniczenie emisji przez wymianę silnika}

Wymiana silnika spalinowego (wymiana silnika 14D40 na silnik 645E3B) skutkuje zmniejszeniem natężenia emisji 

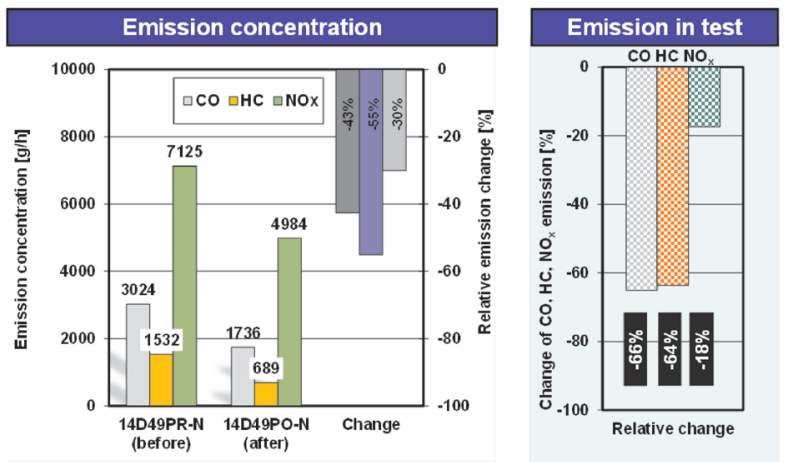

Fig. 13. Analysis of concentration change of emission during repair of engine 14D49

Rys. 13. Analiza zmiany natężenia emisji podczas naprawy silnika $14 D 49$

reduction is from $45 \%$ to almost $70 \%$. It is partly a result of the more modern type of engine, but also the smaller cubic capacity of the new engine. (Fig. 14).

Reduction of concentration of carbon monoxide emission in exhaust gases by $70 \%$ is a result of replacement of combustion engine 14D40 with engine 645E3B. Unfortunately, the concentration of hydrocarbon emission was increased by $30 \%$ (Fig. 15). A small decrease of concentration of nitrogen oxides emission was observed. This is a result of a much smaller capacity of the new combustion engine and its almost twice bigger power.

Reduction of concentration of all exhaust gas components emission is a result of replacement of the combustion engine $645 \mathrm{E} 3 \mathrm{~B}$ with engine $12 \mathrm{CzN} 26 / 26$. This reduction is from $3 \%$ to almost $60 \%$ (Fig. 16). The smallest changes were observed for the concentration of nitrogen oxides emission, which is caused by the lower power of the new engine and its large displacement volume at the same time. A major change was observed in case of hydrocarbons proving the modern design of engine $12 \mathrm{CzN} 26 / 26$.

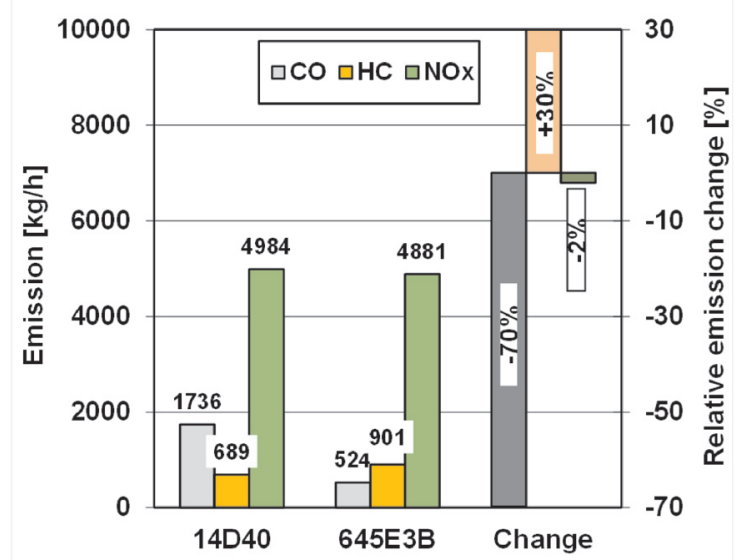

Fig. 15. Analysis of changes in emission concentration during replacement of engine 14D49 with engine 654E3B

Rys. 15. Analiza zmiany natężenia emisji podczas wymiany silnika $14 D 49$ na silnik $654 E 3 B$

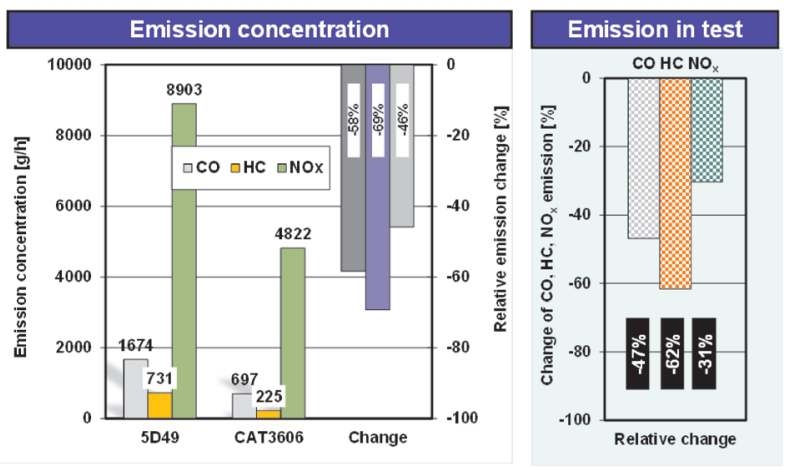

Fig. 14. Analysis of concentration change of emission during replacement of engine 5D49 with engine CAT3606

Rys. 14. Analiza zmiany natężenia emisji podczas wymiany silnika 5D49 na silnik CAT3606

wszystkich składników spalin. Ograniczenie to wynosi od $45 \%$ do prawie $70 \%$. Jest ono częściowo skutkiem nowocześniejszego typu silnika, lecz również mniejszej pojemności skokowej nowego silnika (rys. 14).

Wymiana silnika spalinowego 14D40 na silnik 645E3B skutkuje zmniejszeniem natężenia emisji tlenku węgla w spalinach o 70\%. Niestety, zwiększeniu uległo natężenie emisji węglowodorów o $30 \%$ (rys. 15). Odnotowano niewielkie zmniejszenie natężenia emisji tlenków azotu. Jest to wynikiem znacznie mniejszej pojemności nowego silnika spalinowego i jego prawie dwukrotnie większej mocy.

Zamiana silnika spalinowego 645E3B na silnik 12CzN26/26 skutkuje zmniejszeniem natężenia emisji wszystkich składników spalin. Ograniczenie to wynosi od $3 \%$ do prawie $60 \%$ (rys. 16). Najmniejsze zmiany odnotowano przy natężeniu emisji tlenków azotu, co jest spowodowane mniejszą mocą nowego silnika, a jednocześnie jego dużą objętością skokową. Bardzo dużą zmianę odnotowano w odniesieniu do węglowodorów, co świadczy o nowoczesności konstrukcyjnej silnika 12CzN26/26.

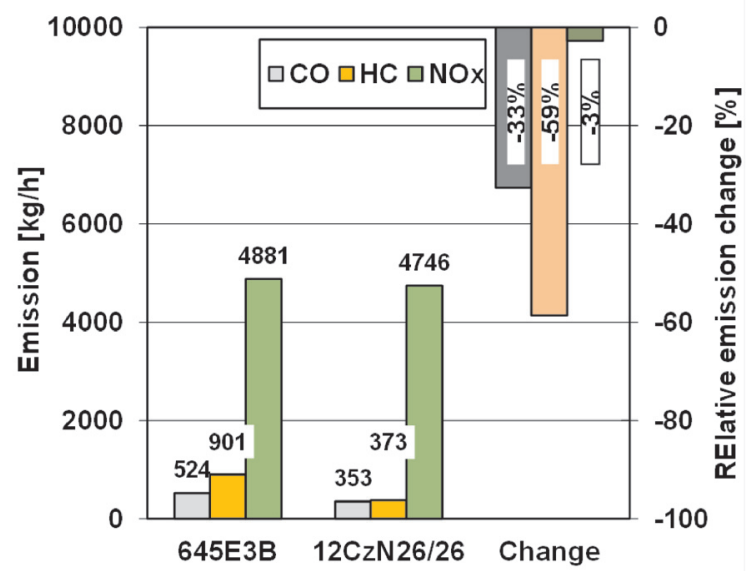

Fig. 16. Analysis of changes in emission concentration during replacement of engine $654 \mathrm{E} 3 \mathrm{~B}$ with engine $12 \mathrm{CzN} 26 / 26$

Rys. 16. Analiza zmiany natężenia emisji podczas wymiany silnika $654 E 3 B$ na silnik $12 C z N 26 / 26$ 


\section{Summary}

Analysis of the emission determined based on the test ISO 8178 leads to obtain the information about the possibility of fulfillment of emission limits by the tested combustion engine. However, this is not the sufficient information on the emission of the individual components to the atmosphere. Their concentration is the direct reason of inter alia the in-

\section{Podsumowanie}

Analiza emisji wyznaczona na podstawie testu ISO 8178 prowadzi do uzyskania informacji o możliwości spełnienia limitów emisji przez poddany badaniom silnik spalinowy. Jednakże nie stanowi wystarczającej informacji o emisji poszczególnych składników do atmosfery. Ich natężenie jest bezpośrednią przyczyną m.in. zwiększonej ilości dwutlenku węgla wywołującego efekt cieplarniany, a natężenie emisji składników toksycznych - tzw. dziury ozonowej i degradacji środowiska. Poniższe zestawienie prezentuje zmiany emisji spalin uzyskane $\mathrm{w}$ teście badawczym ISO 8178-F oraz zmiany natężenia emisji poszczególnych składników spalin (rys. 17). W celu określenia korzyści ekologicznych przedstawiono dane zawierające bezwzględne warto-

creased amount of carbon dioxide causing the greenhouse effect, and the concentration of toxic components emissionso-called the ozone hole and degradation of the environment. The list below presents the changes in exhaust gases emission obtained in research test ISO 8178-F and the changes in concentration of individual exhaust gas components emission (Fig. 17). In order to determine the ecological benefits the data containing the absolute values of the concentration of exhaust gas emission are presented. They are compared with the values of emission obtained in tests in accordance with ISO 8178-F (Fig. 18).

$$
\text { Analysis }
$$
of data of Fig. 16 shows that despite the re-

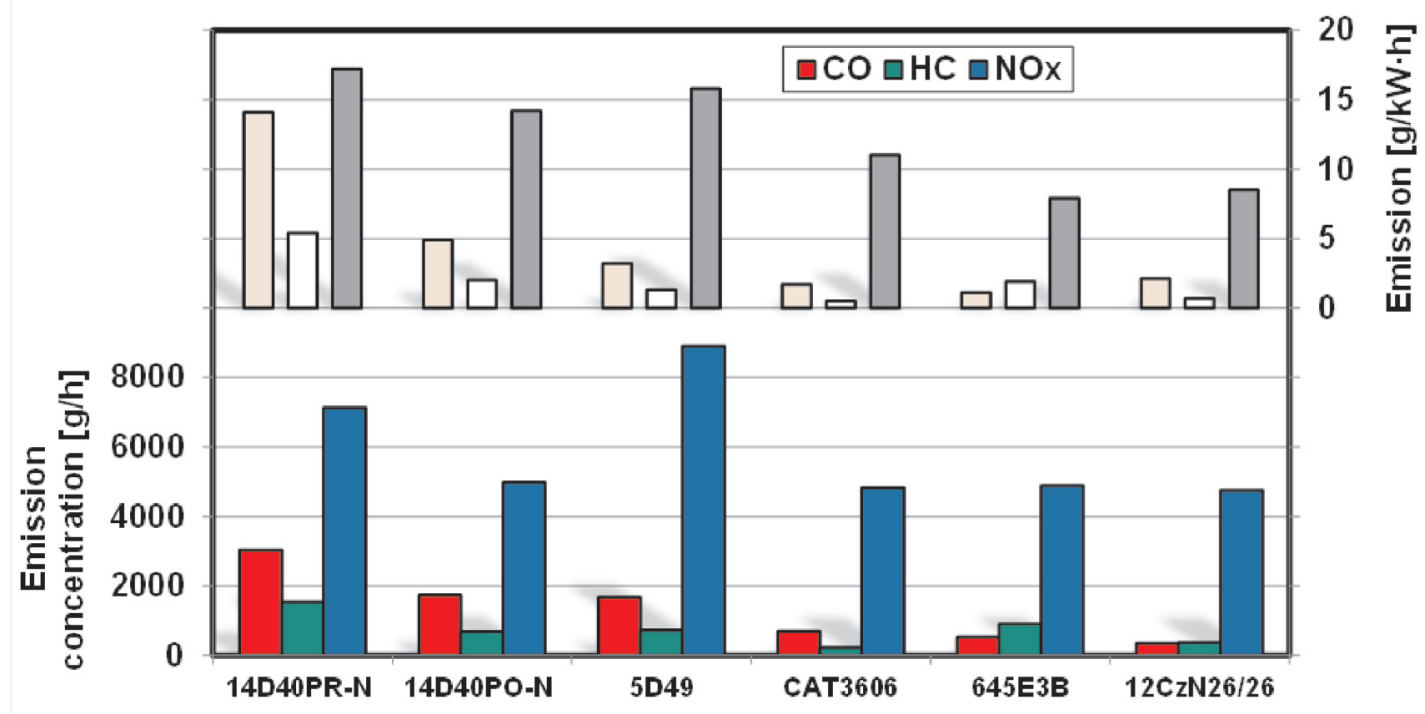

Fig. 18. Absolute changes in emission concentration and exhaust gas emission of locomotives Rys. 18. Bezwzględne zmiany natężenia emisji oraz emisji spalin lokomotyw 
duction of emission concentration, for example the nitrogen oxides from engines $6345 \mathrm{E} 3 \mathrm{~B}$ and $12 \mathrm{CzN} 26 / 26$ in comparison with engine14D40 being repaired, the level of emission concentration of this component remains at the similar level. This means that for this case the reduction of emission concentration of $\mathrm{NO}_{\mathrm{x}}$ is not supported by the environmental protection because the similar amount of nitrogen oxides (with reference to the compound mass) will be emitted to the atmosphere in case of a lack of engine replacement.

The obtained results indicate the need to supplement the emission tests also with the tests of emission concentration, because the analysis and assessment of results only referred to the standards do not allow to assess the ecological benefits of the replaced combustion engines operating in locomotives on the Polish railway routes. się na podobnym poziomie. Oznacza to, że zmniejszenie natężenia emisji NOx w tym przypadku nie zwiększa ochrony środowiska, gdyż wyemitowane zostaną do atmosfery podobne ilości tlenków azotu (w odniesieniu do masy związku), jak w sytuacji braku wymiany silnika.

Uzyskane wyniki świadczą o konieczności uzupełnienia badań emisyjnych również o badania natężenia emisji, gdyż analiza i ocena tylko wyników odniesionych do norm nie pozwala na szacowanie korzyści ekologicznych wymienianych silników spalinowych eksploatowanych w lokomotywach na polskich szlakach kolejowych.

\section{Bibligraphy/Literatura}

[1] Boguś P., Grzeszczyk R., Marciniak Z., Merkisz J., Pielecha I., Pielecha J., Waligórski M.: Misfire detection in exhaust locomotives engines - OBD II/EOBD perspectives. Institute of Machine Design and Operation of the Technical University of Wroclaw, Vol. 86, 2002, s. 45-52.

[2] Directive 2004/26/EC of the European Parliament and of the Council amending Directive 97/68/EC on the approximation of the laws of the Member States relating to measures against the emission of gaseous and particulate pollutants from internal combustion engines to be installed in non-road mobile machinery. 21.04.2004.

[3] Marciniak Z., Merkisz J., Pielecha I., Pielecha J.: Mobile test bed for investigations of toxic components emission of exhaust gases of the diesel engines. Institute of Machine Design and Operation of the Technical University of Wroclaw, Vol. 86, 2002, s. 147-156.

[4] Merkisz J., Pielecha J., Pielecha I.: Road test emissions using on-board measuring method for light duty diesel vehicles, Jordan Journal of Mechanical and Industrial Engineering, Vol. 5, 2011, s. 89-96.
[5] Merkisz J., Pielecha I., Pielecha J., Brudnicki K.: On-road exhaust emissions from passenger cars fitted with a start-stop system. Archives of Transport, Vol. 23, 2011, s. 37-46.

[6] Norma PN-EN ISO 8178-4, Silniki spalinowe tłokowe. Pomiar emisji spalin. Cykle badawcze silników o różnym zastosowaniu, 1999

[7] ISO: Reciprocating internal combustion engines - exhaust emission measurement - Part 1: Test-bed measurement of gaseous and particulate exhaust emissions. Draft International Standard ISO/DIS 8178-1.2, 1995.

[8] http://inforail.pl/text.php?id=52550 (dostęp: 15.02.2013).

[9] European Environment Agency (EEA). European Union emission inventory report 1990-2008 under the UNECE Convention on Long - range Trans-boundary Air Pollution (LRTAP). Technical report No 7/2010.

[10] Railways and the Environment. Building on the Railways' Environmental Strengths, Community of European Railway and Infrastructure Companies (CER), January 2009.

[11] Rail Diesel emissions - facts and challenges. Community of European Railway and Infrastructure Companies. Paris 09.2006 .
Włodzimierz Stawecki, DEng. - Managing Director of the Rail Vehicles Institute TABOR in Poznan.

Dr Włodzimierz Stawecki, prof. nadzw. - dyrektor Instytutu Pojazdów Szynowych TABOR w Poznaniu.

e-mail: sekretariat@tabor.com.pl

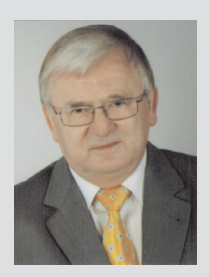

Ireneusz Pielecha, DSc., DEng. - doctor in the Faculty of Machines and Transport at Poznan University of Technology.

Dr hab. inż. Ireneusz Pielecha - adiunkt na Wydziale Maszyn Roboczych i Transportu Politechniki Poznańskiej.

e-mail: ireneusz.pielecha@put.poznan.pl

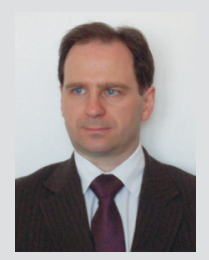

Zygmunt Marciniak, DEng. - head of Department of Locomotives in the Rail Vehicles Institute TABOR in Poznan.

Dr inż. Zygmunt Marciniak, prof. nadzw. - kierownik Zakladu Lokomotyw w Instytucie Pojazdów Szynowych TABOR w Poznaniu. e-mail:lokomotywy@tabor.com.pl

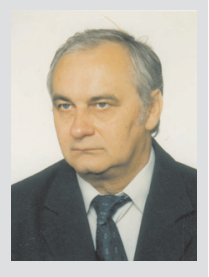

Jacek Pielecha, DSc., DEng. - doctor in the Faculty of Machines and Transport at Poznan University of Technology.

Dr hab. inż. Jacek Pielecha - adiunkt na Wydziale Maszyn Roboczych i Transportu Politechniki Poznańskiej.

e-mail: jacek.pielecha@put.poznan.pl

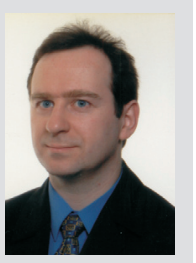

